\title{
Phosphorus Supply of Typical Hungarian Soils
}

\author{
GY. FÜLEKY \\ Szent István University, Department of Soil Science and Agricultural Chemistry, \\ Gödöllő (Hungary)
}

\section{Introduction}

The distribution of phosphorus was investigated in samples collected from the top layer of 12 characteristic Hungarian soils. The fractionation of inorganic phosphorus was carried out with the Chang-Jackson method. During the fractionation procedure the adsorbed, the Al-, Fe- and Ca-bound phosphates were separated. The distribution of organic and inorganic $\mathrm{P}$ varied in the different soils in a way characteristic of the soil type. The amount of weakly bound phosphates was found to be considerable in fertilized soils. Al and Fe phosphates were significant, mainly in meadow and brown forest soils. A negative correlation was found between the amount of $\mathrm{Fe}$ phosphate and the $\mathrm{CaCO}_{3}$ content of soil. In eight of the examined soils Ca phosphates dominated, and they were considerable in all of the other soils (FÜLEKY \& VARGA, 1974). Experimental results show that soil phosphorus status (i.e. the quantity and quality, as well as the ratio of different phosphate forms) depends on the soil type, more exactly on the soils' $\mathrm{pH}$ and $\mathrm{CaCO}_{3}$ content. Above $\mathrm{pH}$ 7 , with the appearance of $\mathrm{CaCO}_{3}$, fraction I increased sharply from a very low level. With increasing $\mathrm{pH}$ the percentage of fraction III decreases, while that of fraction IV - the hardly soluble Ca phosphates - increases. As its amount decreases, the importance of fraction III - from the point of view of fertilizer P fixation - diminishes as well. The importance of fraction II is not dependent on $\mathrm{pH}$. In the case of calcareous soils the variably soluble $\mathrm{Ca}$ phosphates, in non-calcareous soils chiefly the $\mathrm{Al}$ and easily soluble $\mathrm{Ca}$ phosphates as well as Fe phosphates influence the soil phosphorus status. Adsorbed phosphates are important only in calcareous soils. There is a relationship between the above-mentioned soil characteristics and the alteration of the soil phosphorus status due to $\mathrm{P}$ fertilization. After $\mathrm{P}$ fertilization fertilizer P can be found primarily in fractions II and III in non-calcareous soils and in fractions I, II and IV in calcareous soils (FÜLEKY, 1975). In small pots the phosphorus uptake of ryegrass plants reduced first of all the quantity of easily soluble $\mathrm{Ca}$ phosphates, and Al phosphates as well as Fe-phosphates in non-calcareous soils, and sorbed phosphates, Al phosphate and variably soluble $\mathrm{Ca}$ phosphates (fraction I, II and IV) in calcareous soils. A significant relation could be found only between

Correspondence to: György FÜLEKY, Szent István University, Department of Soil Science and Agrochemistry, H-2103 Gödöllö, Páter Károly u. 1. Hungary. E-mail: fuleky.gyorgy@ mkk.szie.hu 
the quantity of fraction II and the phosphorus uptake of plants for all the studied soil types. It was concluded that fraction II (Al phosphate and easily soluble Ca phosphates) is the main phosphorus source of plants in both calcareous and noncalcareous soils with or without P fertilization (FÜLEKY, 1979a). The available phosphorus content determined with some extractants was closely related to the Chang-Jackson inorganic phosphate fractions I and II, namely to the weakly bound phosphates, the easily soluble $\mathrm{Ca}$ phosphates and $\mathrm{Al}$ phosphates. In calcareous soils available $\mathrm{P}$ was more closely related to fraction I, in non-calcareous soils to fraction II (FÜLEKY, 1976).

On 36 soils collected from different soil types of Hungary a pot experiment was conducted with ryegrass test plants. Considering all of the calcareous and noncalcareous soils together the Olsen-P and $\mathrm{H}_{2} \mathrm{O}-\mathrm{P}$ were in very close correlation $(\mathrm{r}=$ 0.860 and $\mathrm{r}=0.870$, resp.) with $\mathrm{P}$ response, while only a weak correlation $(\mathrm{r}=$ 0.580 ) could be established between AL-P and P response. When separating the soils into calcareous and non-calcareous soil groups, the relationship was closer using the AL-P method (FÜLEKY \& KRÁMER, 1979).

Present study aims to determine the role of inorganic phosphate fractions in the phosphorus supply of Hungarian soils, and to evaluate the new Hot Water Percolation (HWP) method with ryegrass plants in a pot experiment.

\section{Materials and Methods}

Some properties of the 36 soils used in the experiment are given in Table 1 and by FÜLEKY (1987). Soil samples - weighing $1 \mathrm{~kg}$ each - were placed in plastic pots in 3 replications. Prior to the pot experiment $100 \mathrm{mg}$ nitrogen was mixed into the soil and the moisture content was adjusted to field water capacity. Pots were sown with 1-1 g ryegrass seed and the plants were grown under greenhouse conditions. Shoots were cut 6 times (every 3 weeks). A further $50 \mathrm{mg} \mathrm{N}$ was added weekly in solution form. The phosphorus content was measured in air-dry shoot samples and the phosphorus taken up by plants was calculated. Results of the pot experiment can be found in Table 1 .

In the original soil samples $\mathrm{pH}_{\mathrm{KCl}}$, and $\mathrm{CaCO}_{3}$ content, ammonium lactate - acetate soluble phosphate (AL-P) (THAMM et al., 1968) content were determined in addition to the Chang-Jackson phosphate fractions (FÜLEKY \& VARGA, 1974). The hot water extractable phosphate content (HWP-P) of soils was determined with a new method developed in our laboratory (FÜLEKY \& CZINKOTA, 1993). For the kinetic approach of soil phosphorus supply $100 \mathrm{~cm}^{3}$ solutions were collected five times. The first $100 \mathrm{~cm}^{3}$ is designated as HWP- $\mathrm{P}_{1 \mathrm{st}}$ in the text. The data were fitted to the equation of the first order kinetic reaction $\left(\mathrm{Y}=\mathrm{A}\left(1-\mathrm{e}^{\mathrm{kt}}\right)\right.$ for the formal kinetic description of the process, where $Y$ is the amount of $\mathrm{P}$ released, $k$ is the rate constant, $t$ is the time and A (HWP-P ${ }_{\max }$ in the text) is the maximum amount of soluble phosphates (Fig. 1). 


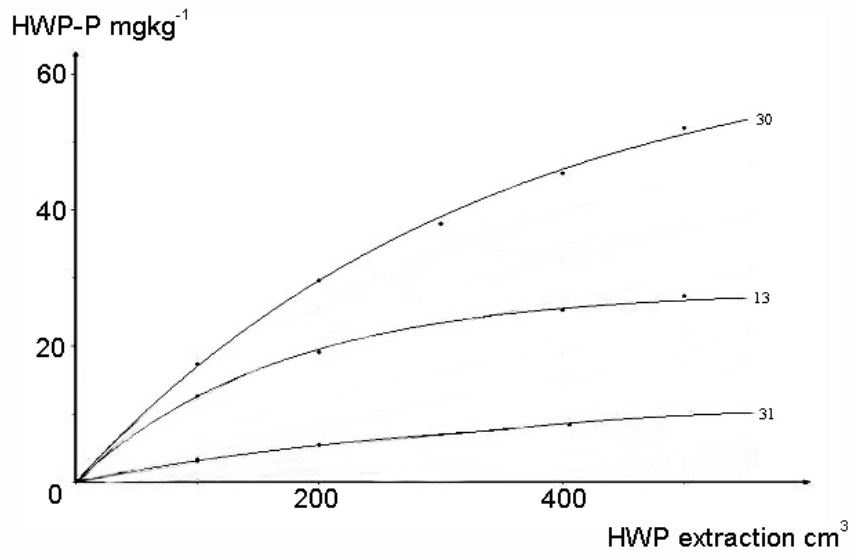

Fig. 1

Hot water extraction (HWP) of soil phosphorus in the case of soils No. 13, 30 and 31

\section{Results and Discussion}

Former results regarding the distribution of inorganic phosphate fractions were only proven in the case of a few soils out of the studied 36 Hungarian soils (FÜLEKY, 1983). The main conclusion is the close correlation between $\mathrm{pH}$ and the Fe phosphate (III) fraction (Fig. 2).

This relationship and also the $\mathrm{pH}$ dependence of hardly soluble $\mathrm{Ca}$ phosphate (IV) fraction (Fig. 3) is the consequence of soil developing processes. It is a hyperbolic relationship between the amount of fraction IV and the $\mathrm{pH}_{\mathrm{KCl}}$. At low $\mathrm{pH}$ (3 to 4) this fraction amounts to less than $100 \mathrm{mg} \cdot \mathrm{kg}^{-1}$. With $\mathrm{pH}$ increasing to above 7 , when carbonates are in the system, the quantity of this fraction exceeds $200 \mathrm{mg} \cdot \mathrm{kg}^{-1}$ and suddenly reaches $400-600 \mathrm{mg} \cdot \mathrm{kg}^{-1}$.

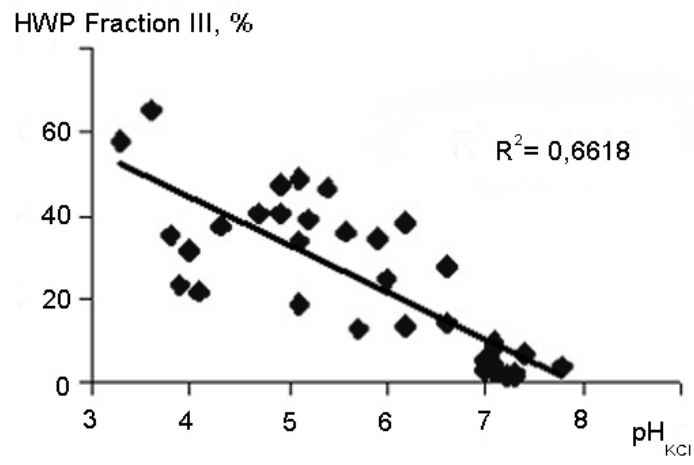

Fig. 2

Relationship between $\mathrm{pH}$ and the ratio of Fe phosphate (fraction III) in the case of the studied $(\mathrm{n}=36)$ Hungarian soils 
Table 1

Some properties and the inorganic phosphate fractions of the studied Hungarian soils

\begin{tabular}{|c|c|c|c|c|c|c|c|c|}
\hline \multirow{3}{*}{\multicolumn{2}{|c|}{$\begin{array}{l}\text { No. of soil and } \\
\text { place of origin }\end{array}$}} & \multirow{3}{*}{$\mathrm{pH}_{\mathrm{KCl}}$} & \multirow{2}{*}{$\mathrm{CaCO}_{3}$} & \multirow{2}{*}{$\mathrm{AL}-\mathrm{Ca}$} & \multicolumn{4}{|c|}{$\begin{array}{l}\text { Inorganic phosphate } \\
\text { fractions }\end{array}$} \\
\hline & & & & & I & II & III & IV \\
\hline & & & $\%$ & \multicolumn{5}{|c|}{$\mathrm{mg} \cdot \mathrm{kg}^{-1}$} \\
\hline 1. & Kenyeri & 6.2 & 0 & 184 & 30 & 87 & 110 & 61 \\
\hline 2. & Agyagosszergény & 7.1 & 1.3 & 630 & 21 & 80 & 36 & 254 \\
\hline 3. & Keszthely & 6.6 & 0 & 238 & 2.6 & 22 & 27 & 133 \\
\hline 4. & Nagykanizsa & 4.3 & 0 & 95 & 5.7 & 49 & 102 & 119 \\
\hline 5. & Magyaróvár & 7.2 & 27 & 2605 & 35 & 30 & 6.6 & 422 \\
\hline 6. & Nagyszentjános & 7.3 & 7.2 & 1398 & 81 & 125 & 9.6 & 604 \\
\hline 7. & Homokszentgyörgy & 4.0 & 0 & 47 & 10 & 102 & 100 & 109 \\
\hline 8. & Orosháza & 7.1 & 1.7 & 666 & 2.3 & 27 & 16 & 294 \\
\hline 9. & Mezőhegyes & 7.1 & 5 & 1118 & 4.8 & 44 & 9.6 & 383 \\
\hline 10. & Új-Szeged & 7.1 & 2.1 & 702 & 3.7 & 32 & 34 & 327 \\
\hline 11. & Szeged-Öthalom & 7.3 & 6 & 1148 & 17 & 67 & 11 & 448 \\
\hline 12. & Nyirlugos & 3.9 & 0 & 48 & 1.5 & 24 & 38 & 97 \\
\hline 13. & Nyiregyháza & 4.1 & 0 & 59 & 5.8 & 53 & 67 & 184 \\
\hline 14. & Kompolt & 5.1 & 0 & 333 & 2.4 & 26 & 51 & 26 \\
\hline 15. & Tiborszállás & 3.6 & 0 & 369 & 5.5 & 114 & 267 & 26 \\
\hline 16. & Iregszemcse & 7.1 & 6.9 & 1070 & 7.7 & 49 & 15 & 500 \\
\hline 17. & Kecskemét & 7.8 & 12 & 2153 & 9.6 & 24 & 9.6 & 221 \\
\hline 18. & Nagyhörcsög & 7.0 & 1.8 & 571 & 3.5 & 47 & 26 & 447 \\
\hline 19. & Hajdúböszörmény & 5.7 & 0 & 440 & 2.9 & 30 & 28 & 153 \\
\hline 20. & Magyaregregy & 5.1 & 0 & 345 & 1.7 & 43 & 122 & 198 \\
\hline 21. & Hajdúszoboszló & 6.0 & 0 & 339 & 2.8 & 36 & 50 & 117 \\
\hline 22. & Karcag & 4.7 & 0 & 297 & 1.9 & 35 & 74 & 73 \\
\hline 23. & Sarkad & 5.4 & 0 & 398 & 6.6 & 78 & 124 & 60 \\
\hline 24. & Ragály & 3.3 & 0 & 48 & 1.6 & 17 & 48 & 16 \\
\hline 25. & Szilvásvárad & 6.6 & 0 & 440 & 81 & 199 & 149 & 105 \\
\hline 26. & Etes & 5.9 & 0 & 452 & 47 & 246 & 201 & 87 \\
\hline 27. & Eger & 5.6 & 0 & 356 & 22 & 207 & 177 & 84 \\
\hline 28. & Szarvas & 4.9 & 0 & 273 & 2.8 & 57 & 110 & 104 \\
\hline 29. & Martonvásár & 6.2 & 0 & 321 & 1.5 & 27 & 44 & 254 \\
\hline 30. & Gagyvendégi & 5.2 & 0 & 214 & 18 & 278 & 228 & 61 \\
\hline 31. & Putnok & 3.8 & 0 & 166 & 5.9 & 84 & 137 & 165 \\
\hline 32. & Szentgyörgyvölgy & 4.9 & 0 & 107 & 3.8 & 44 & 105 & 71 \\
\hline 33. & Hosszúhát & 5.1 & 0 & 261 & 3 & 38 & 60 & 228 \\
\hline 34. & Örbottyán & 7.4 & 3.3 & 720 & 3 & 23 & 20 & 233 \\
\hline 35. & Csávoly & 7.1 & 2.6 & 690 & 12 & 86 & 65 & 503 \\
\hline 36. & Ozsákpuszta & 7.0 & 14 & 1273 & 8.5 & 63 & 12 & 355 \\
\hline
\end{tabular}

Remarks: HWP-P: hot water extractable P according to FÜLEKY \& CZINKOTA (1993)

Efforts were made to find a method that can follow this trend with a linear relationship. AL-soluble Ca was the parameter capable of producing this relation (Fig. 4).

In calcareous soils, containing $\mathrm{CaCO}_{3}$ or a high amount of exchangeable $\mathrm{Ca}$ ions, the ratio of hardly soluble Ca phosphates (fraction IV) is high, but in acidic 
Table 1 continued

\begin{tabular}{|c|c|c|c|c|c|c|c|c|c|c|c|}
\hline \multicolumn{4}{|c|}{$\begin{array}{l}\text { Ratio of inorganic phos- } \\
\text { phate fractions }\end{array}$} & \multirow{2}{*}{$\begin{array}{c}\text { P uptake } \\
\text { (meas- } \\
\text { ured) }\end{array}$} & \multicolumn{4}{|c|}{$\begin{array}{l}\text { Change of inorganic phos- } \\
\text { phate fractions }\end{array}$} & \multirow{2}{*}{$\begin{array}{c}\text { HWP- } \\
\mathrm{P}_{1 \mathrm{st}}\end{array}$} & \multirow{2}{*}{$\begin{array}{l}\text { HWP- } \\
\mathrm{P}_{\max }\end{array}$} & \multirow[t]{2}{*}{ AL-P } \\
\hline I & II & III & IV & & $\Delta \mathrm{I}$ & $\Delta \mathrm{II}$ & $\Delta \mathrm{III}$ & $\Delta \mathrm{IV}$ & & & \\
\hline \multicolumn{4}{|c|}{$\%$} & \multicolumn{8}{|c|}{$\mathrm{mg} \cdot \mathrm{kg}^{-1}$} \\
\hline 11 & 30 & 38 & 21 & 44 & 21 & 33 & 24 & 10 & 5.2 & 29 & 91 \\
\hline 5.3 & 21 & 9.2 & 65 & 35 & 15 & 35 & 5.3 & 68 & 2.1 & 9.1 & 95 \\
\hline 1.4 & 12 & 15 & 72 & 11 & 0.6 & 3.6 & 4.3 & 24 & 0.9 & 4.2 & 17 \\
\hline 2.1 & 18 & 37 & 43 & 33 & 2.6 & 11 & 9.5 & 27 & 7.6 & 28 & 44 \\
\hline 7.0 & 6.1 & 1.3 & 86 & 28 & 25 & 4.4 & 0.1 & 77 & 1.1 & 8.4 & 100 \\
\hline 9.4 & 15 & 12 & 74 & 40 & 37 & 28 & 1.9 & 91 & 2.1 & 8.1 & 254 \\
\hline 32 & 32 & 31 & 34 & 50 & 5.3 & 31 & 30 & 38 & 17 & 41 & 88 \\
\hline 0.7 & 7.9 & 4.6 & 87 & 7.5 & 0.1 & 1.3 & 2.1 & 64 & 0.7 & 3.8 & 49 \\
\hline 1.1 & 9.9 & 22 & 87 & 12 & 0.9 & 8.0 & 0.1 & 59 & 0.9 & 6.9 & 89 \\
\hline 0.9 & 8.1 & 8.5 & 82 & 8.5 & 1.7 & 6.6 & 1.0 & 80 & 1.0 & 5.9 & 59 \\
\hline 3.1 & 12 & 2.1 & 83 & 10 & 5.1 & 8.3 & 0.1 & 22 & 1.2 & 6.0 & 133 \\
\hline 0.9 & 15 & 24 & 61 & 9.8 & 0.1 & 6.2 & 19 & 43 & 2.7 & 8.6 & 18 \\
\hline 1.9 & 17 & 22 & 59 & 38 & 2.9 & 19 & 16 & 73 & 13.5 & 28 & 50 \\
\hline 2.3 & 24 & 49 & 24 & 11 & 0.8 & 9.8 & 15 & 13 & 1.2 & 7.6 & 11 \\
\hline 1.1 & 28 & 65 & 62 & 31 & 2.5 & 45 & 68 & 11 & 3.9 & - & 55 \\
\hline 1.3 & 8.5 & 2.7 & 87 & 22 & 3.8 & 9.6 & 0.7 & 45 & 1.1 & 6.2 & 82 \\
\hline 3.6 & 8.9 & 3.6 & 84 & 11 & 3.2 & 9 & 5.5 & 42 & 1.5 & 2.8 & 45 \\
\hline 0.7 & 89 & 5.0 & 85 & 15 & 0.4 & 106 & 7.9 & 47 & 1.2 & 6.6 & 52 \\
\hline 1.4 & 14 & 13 & 71 & 13 & 1.0 & 5.2 & 8.0 & 63 & 1.9 & 8.1 & 21 \\
\hline 0.5 & 12 & 33 & 54 & 30 & 0.1 & 7.1 & 14 & 9.1 & 1.2 & 7.6 & 59 \\
\hline 1.4 & 17 & 24 & 57 & 23 & 1.3 & 11 & 9.7 & 31 & 1.4 & 7.5 & 27 \\
\hline 1.0 & 19 & 40 & 40 & 16 & 0.4 & 14 & 12 & 41 & 1.2 & 6.6 & 13 \\
\hline 2.5 & 29 & 46 & 22 & 41 & 4.4 & 24 & 23 & 2.9 & 3.0 & 9.4 & 91 \\
\hline 1.9 & 21 & 58 & 20 & 9.3 & 0.5 & 0.2 & 2.9 & 7.5 & 2.7 & 15 & 8.9 \\
\hline 15 & 37 & 28 & 20 & 73 & 41 & 69 & 30 & 1.9 & 13 & 49 & 329 \\
\hline 8.1 & 42 & 35 & 15 & 88 & 15 & 96 & 13 & 14 & 11 & 37 & 354 \\
\hline 4.6 & 42 & 36 & 17 & 81 & 9.4 & 78 & 25 & 9.8 & 15 & 57 & 325 \\
\hline 1.0 & 21 & 40 & 38 & 35 & 0.8 & 24 & 16 & 8.0 & 2.3 & 9.4 & 52 \\
\hline 0.5 & 8.3 & 13 & 78 & 18 & 0.1 & 6.4 & 14 & 25 & 0.6 & 2.9 & 27 \\
\hline 3.0 & 48 & 39 & 10 & 59 & 3.9 & 142 & 37 & 6.6 & 18 & 66 & 270 \\
\hline 1.5 & 21 & 35 & 42 & 27 & 3.3 & 51 & 54 & 121 & 2.6 & 21 & 34 \\
\hline 1.7 & 20 & 47 & 32 & 15 & 1.7 & 27 & 11 & 35 & 1.3 & 6.4 & 9.8 \\
\hline 0.9 & 12 & 18 & 70 & 24 & 1.3 & 18 & 33 & 150 & 2.0 & 8.5 & 37 \\
\hline 1.1 & 8.1 & 7.1 & 84 & 11 & 0.1 & 5.1 & 6.1 & 74 & 0.7 & 2.4 & 28 \\
\hline 1.7 & 13 & 9.8 & 76 & 30 & 0.1 & 12 & 35 & 42 & 3.3 & 11 & 174 \\
\hline 1.9 & 15 & 2.6 & 81 & 11 & 6.2 & 46 & 0.6 & 45 & 0.7 & 3.9 & 47 \\
\hline
\end{tabular}

brown forest soils this ratio is no more than $60 \%$ (Table 1 ). At the same time the amount of $\mathrm{Fe}$ phosphate (fraction III) shows the opposite relationship. The determination of inorganic phosphate fractions not only helps in discovering the source of soil phosphorus supply and the fate of fertilizer phosphorus, but enhances following soil development and better soil classification (FÜLEKY, 1979b). 


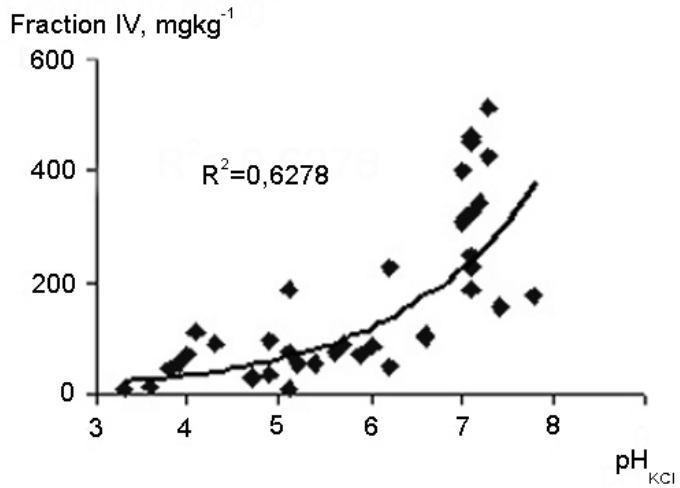

Fig. 3

Relationship between $\mathrm{pH}$ and the amount of hardly soluble Ca phosphates (fraction IV),

$$
\mathrm{n}=36
$$

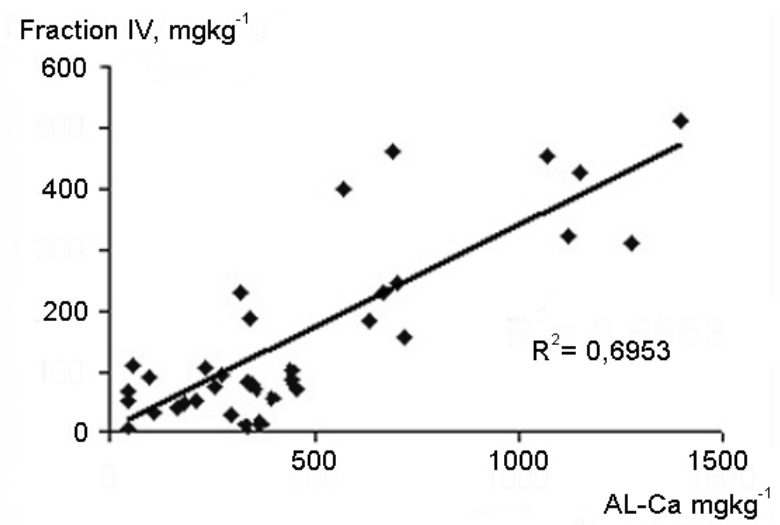

Fig. 4

Relationship between AL-soluble Ca and hardly soluble Ca phosphates (fraction IV),

$$
\mathrm{n}=36
$$

There are some good examples among the 36 soils analysed. Soil No. 14. was classified as chernozem brown forest soil, however, the ratio of fraction IV (the hardly soluble Ca phosphates) was only $24 \%$, as compared to the typical chernozems in which this ratio is about $80 \%$. In soil No. 21., classified as leached chernozem, the ratio of hardly soluble Ca phosphates was only $57 \%$. This is not so problematic, but at the same time the ratio of Fe phosphate (fraction III) was too high (24\%). Soil No. 29. from Martonvásár produces a quite good phosphate distribution, fitting well to its classification as chernozem with forest residues. The ratio of hardly soluble Ca phosphates (fraction IV) is $78 \%$ in this soil.

The average amounts and ratio of inorganic phosphate fractions were calculated for three soil groups. The first was the brown forest soil group with 14 soils, the second was the meadow soil group with 8 soils and the third was the calcareous soil 
group with 14 soils. In Table 2 it can be seen that fraction I (the adsorbed and solution phosphates) amounts only to a few percent (2-4\%) in all three soil groups. The amount of fraction II (the weakly bound Ca phosphates and the $\mathrm{Al}$ phosphates) is in average $10 \%, 20 \%$ and $26 \%$ in calcareous, meadow and brown forest soils, resp. In accordance with our former results (FÜLEKY, 1983) fraction III (the Fe phosphate fraction) shows a typical distribution in the main soil groups. The ratio of fraction III in calcareous soils is below $10 \%$, in meadow and brown forest soils - as a con-

Table 2

Average distribution of inorganic phosphate fractions in the soil samples grouped into three main soil groups

\begin{tabular}{|c|c|c|c|c|}
\hline $\begin{array}{c}\text { Inorganic } \\
\text { phosphate } \\
\text { fraction }\end{array}$ & $\begin{array}{c}\text { Brown forest } \\
\text { soils } \\
(n=14)\end{array}$ & $\begin{array}{l}\text { Meadow soils } \\
\quad(\mathrm{n}=8)\end{array}$ & $\begin{array}{l}\text { Calcareous soils } \\
\qquad(\mathrm{n}=14)\end{array}$ & $\mathrm{LSD}_{5 \%}$ \\
\hline \multicolumn{5}{|c|}{ Ratio of inorganic phosphate fractions, \% $\Sigma I-I V$. } \\
\hline I & 3.866 & 1.83 & 1.88 & 2.41 \\
\hline II & 26.627 & 19.75 & 10.25 & 6.05 \\
\hline III & 36.772 & 29.21 & 7.27 & 10.71 \\
\hline IV & 32.680 & 48.24 & 80.55 & 13.88 \\
\hline \multicolumn{5}{|c|}{ Change in inorganic phosphate fraction, $\Delta, \mathrm{mg} \mathrm{kg}^{-1}$} \\
\hline$\Delta \mathrm{I}$ & 7.68 & 7.79 & 3.50 & 7.71 \\
\hline$\Delta \mathrm{II}$ & 41.37 & 24.08 & 16.91 & 24.28 \\
\hline$\Delta \mathrm{III}$ & 21.40 & 20.96 & 6.27 & 10.85 \\
\hline$\Delta \mathrm{IV}$ & 41.93 & 54.31 & 48.29 & 36.57 \\
\hline
\end{tabular}

sequence of soil development - it is about $30 \%$. Fraction IV (the hardly soluble $\mathrm{Ca}$ phosphates) shows the opposite distribution in the 36 soils: in calcareous soils its ratio is more than $80 \%$, in meadow soils near $50 \%$ and in brown forest soils only $30 \%$.

The role of inorganic phosphate fractions in the phosphorus supply of plants was calculated. For this purpose the inorganic phosphate fractions were determined before and after growing ryegrass on soils. The results were calculated on the average of three soil groups (Table 2). The decrease in the quantity of fraction I was 3.5 $\mathrm{mg} \cdot \mathrm{kg}^{-1}$ for calcareous soils and near $8 \mathrm{mg} \cdot \mathrm{kg}^{-1}$ for meadow and brown forest soils. The decrease in the amount of fraction II was 40,24 and $17 \mathrm{mg} \cdot \mathrm{kg}^{-1}$ for brown forest soils, meadow soils and calcareous soils, resp. The decrease in fraction III (the Fe phosphates) was around $21 \mathrm{mg} \cdot \mathrm{kg}^{-1}$ in meadow and brown forest soils and much less (about $6 \mathrm{mg} \cdot \mathrm{kg}^{-1}$ ) in calcareous soils. Fraction IV (the hardly soluble Ca phosphates) decreased by 42,54 and $48 \mathrm{mg} \cdot \mathrm{kg}^{-1}$ in the case of brown forest soils, meadow soils and calcareous soils, resp.

The relationship between the rate of decrease in the amount of phosphate fractions as the consequence of plant phosphorus uptake was also considered. It can be seen (Table 1) that the rate of decrease in phosphate fractions is higher than the total 
plant phosphorus uptake. In this direct way it was possible to determine only the changes in the phosphate fractions induced by plant growing and nutrition. Possibly indirect calculation could give a more realistic picture.

Table 3

Linear correlation of inorganic soil phosphate fractions with ryegrass $\mathrm{P}$ uptake and chemical extractions $(n=36)$

\begin{tabular}{|c|c|c|c|c|c|}
\hline \multirow{2}{*}{\multicolumn{2}{|c|}{$\begin{array}{c}\text { Plant uptake } \\
\text { P uptake by ryegrass }\end{array}$}} & \multicolumn{4}{|c|}{ Chemical extraction } \\
\hline & & \multicolumn{2}{|c|}{ AL-P } & \multicolumn{2}{|c|}{ HWP-P ${ }_{\max }$} \\
\hline $\begin{array}{c}\text { Inorganic } \\
\text { phosphate } \\
\text { fraction }\end{array}$ & $\mathrm{R}^{2}$ & $\begin{array}{c}\text { Inorganic } \\
\text { phosphate } \\
\text { fraction }\end{array}$ & $\mathrm{R}^{2}$ & $\begin{array}{c}\text { Inorganic } \\
\text { phosphate } \\
\text { fraction }\end{array}$ & $\mathrm{R}^{2}$ \\
\hline I & 0.6969 & I & 0.6053 & I & 0.1658 \\
\hline II & 0.7719 & II & 0.8085 & II & 0.7296 \\
\hline III & 0.6385 & III & 0.3243 & III & 0.6601 \\
\hline IV & 0.0127 & IV & 0.1123 & IV & 0.0094 \\
\hline$\Delta \mathrm{I}$ & 0.2913 & & & $\Delta \mathrm{I}$ & 0.1152 \\
\hline$\Delta \mathrm{II}$ & 0.4250 & & & $\Delta \mathrm{II}$ & 0.5031 \\
\hline$\Delta \mathrm{II}$. & 0.1545 & & & $\Delta \mathrm{III}$ & 0.3148 \\
\hline$\Delta \mathrm{IV}$ & 0.0953 & & & $\Delta \mathrm{IV}$ & 0.1063 \\
\hline & & & & I \% & 0.2875 \\
\hline & & & & II \% & 0.7586 \\
\hline & & & & III \% & 0.1834 \\
\hline & & & & IV \% & 0.5767 \\
\hline
\end{tabular}

Remarks: AL-P (THAMM et al., 1968); HWP-P (FÜLEKY \& CZINKOTA, 1993)

The most close correlation between plant $\mathrm{P}$ uptake and the phosphate fractions was obtained in the case of fraction II $\left(\mathrm{R}^{2}=0.7719\right)$, followed by fraction III $\left(\mathrm{R}^{2}=\right.$ 0.6385 ) (Table 3). The rate of decrease in the amount of phosphate fraction II was only in close correlation with ryegrass phosphorus uptake $\left(\mathrm{R}^{2}=0.4250\right)$.

Relationships between the methods used for the determination of soil phosphorus supply and the inorganic phosphate fractions were also calculated (Table 3 ) (Fig. 5). The AL method and the new HWP method developed in our laboratory were both in close linear correlation with fraction II. In addition, the HWP method correlated well with fraction III. The recognized hyperbolic relationship between fraction IV\% and the HWP phosphorus results is interesting. According to this relation, when the ratio of fraction IV (the hardly soluble Ca phosphates) increases, the phosphorus amount measurable with hot water extraction decreases along a hyperbolic function (Fig. 6).

The correlations between the methods used for the determination of soil phosphorus supply and the plant $\mathrm{P}$ uptake are shown in Fig. 5. All the used methods, including fraction II as well, correlate well with the plant $\mathrm{P}$ uptake. The only shortcoming of the HWP method is the more narrow measuring interval $\left(0-100 \mathrm{mg} \cdot \mathrm{kg}^{-1}\right)$ as compared to the $\mathrm{AL}$ method $\left(0-400 \mathrm{mg} \cdot \mathrm{kg}^{-1}\right)$. In addition to the 5 -step hot water 


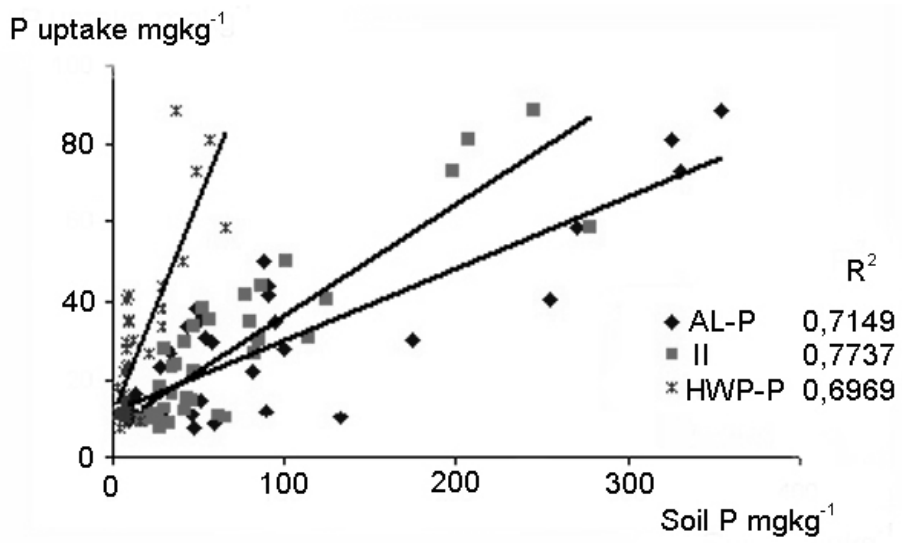

Fig. 5

Relationship between soil chemical extraction methods and ryegrass phosphorus uptake, $\mathrm{n}=36$

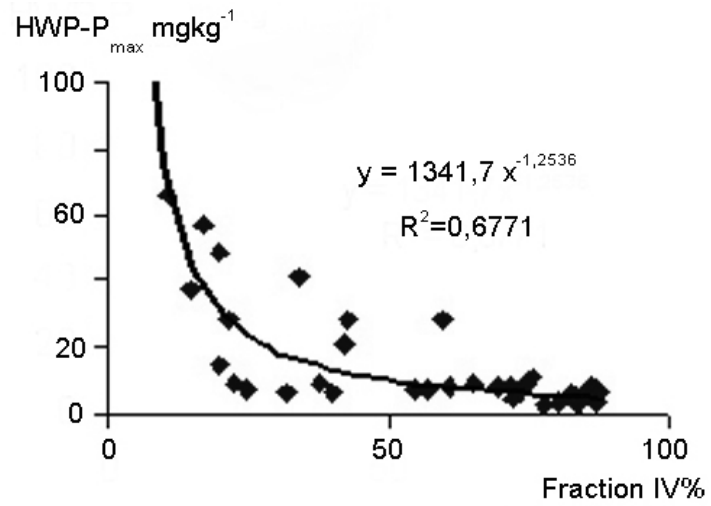

Fig. 6

Dependence of hot water soluble phosphates on the ratio of hardly soluble Ca phosphates (Fraction IV), $\mathrm{n}=36$

extraction the shorter variation of this method was tested as well. Using the first 100 $\mathrm{cm}^{3}$ of the HWP solution and determining the phosphate content, the correlation between this fraction and ryegrass $\mathrm{P}$ uptake was also close $\left(\mathrm{R}^{2}=0.6272\right)$. This underlines the usefulness of the HWP method in routine analysis.

\section{Summary}

The new hot water percolation (HWP) method was introduced to determine the phosphorus supply of soils from the Soil Bank of 36 Hungarian soils. The present work aimed to explain the availability of phosphorus by determining the inorganic phosphate fractions and using ryegrass test plants. Four inorganic phosphate frac- 
tions were distinguished: Fraction I, the sorbed phosphates; Fraction II, the easily soluble $\mathrm{Ca}$ phosphates and the $\mathrm{Al}$ bound phosphates; Fraction III, the Fe phosphates; and Fraction IV, the hardly soluble Ca phosphates. Fraction II, in which the easily soluble Ca phosphates and Al phosphates accumulate, was the main phosphorus source for the test plants on both calcareous and non-calcareous soils. Fraction III (the iron phosphates) plays a greater role in non-calcareous soils, while Fraction IV (the hardly soluble Ca phosphates) in calcareous soils. Both fractions are closely connected with soil development, and with soil properties such as $\mathrm{pH}$ and $\mathrm{CaCO}_{3}$ content.

The hot water percolation method reflects the phosphorus supply of soil as well as that measured with ryegrass plants and with the AL method. This new HWP method is in good correlation with the main source of phosphate, with fraction II. For routine purposes the first collected HWP fraction can possibly be used to determine the phosphorus supply of soil correlating well with the phosphorus uptake of test plants.

Key words: hot water percolation, inorganic phosphate fractions, $\mathrm{P}$ uptake

\section{References}

FÜLEKY, GY., 1975. Changes of the soil phosphorus status in long-term field experiments. II. (In Hungarian) Agrokémia és Talajtan. 24. 291-302.

FÜLEKY, GY., 1976. Investigation on some extractants used for the evaluation of available phosphorus. (In Hungarian) Agrokémia és Talajtan. 25. 271-296.

FÜLEKY, GY., 1979a. Nutrient supply of soil measured in small-pots I. Interaction between phosphorus uptake of the plants and phosphorus status of the soils. (In Hungarian) Agrokémia és Talajtan. 28. 143-156.

FÜLEKY, GY., 1979b. Phosphate dynamics in the Újszentmargitta solonetz soil. (In Hungarian) Agrokémia és Talajtan. 28. 105-122.

FÜLEKY, GY., 1983. Phosphorus status of characteristic soil types. (In Hungarian) Agrokémia és Talajtan. 32. 7-30.

FÜLEKY, GY., 1987. Potassium supply in typical soils of Hungary. Bulletin of the University of Agricultural Sciences, Gödöllö. 1. 113-119.

FÜLEKY, Gy. \& CZINKOTA, I., 1993. Hot water percolation (HWP): A new rapid soil extraction method. Plant and Soil. 157. 131-135.

FüLEKY, GY. \& KRÁMER, M., 1979. Relationship between easily soluble P content of soil and P response. (In Hungarian) In: Yearbook of the Research Institute for Soil Science and Agricultural Chemistry. 163-165. RISSAC. Budapest.

FÜLEKY, GY. \& VARGA, GY., 1974. The distribution of phosphorus compounds in characteristic Hungarian soils. (In Hungarian) Agrokémia és Talajtan. 23. 41-52.

THAMM, F.-NÉ, KRÁMER, M. \& SARKADI, J., 1968. Determination of P content in plants and manures with ammonium molibdo vanadate method. (In Hungarian) Agrokémia és Talajtan. 17. 145-156. 